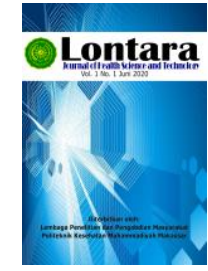

Lontara

Journal of Health Science and Technology

http://jurnal.poltekkesmu.online/lontarariset

Vol 1, No. 2, December 2020, pp 80-86

p-ISSN:0000-0000 dan e-ISSN: 2721-6179

DOI:https://doi.org/

\title{
Studi Kandungan Bahan Tambahan Makanan Pada Minuman Thai Tea Di Sekitar Kampus Politeknik Kesehatan Muhammadiyah Makassar
}

\author{
A. M. Fadhil Hayat, Baharuddin Sunu, Muhammad Ikbal Abbas, Indah Islamia \\ Sanitasi, Politeknik Kesehatan Muhammadiyah Makassar \\ Email: fadhil.hayat71@gmail.com
}

\section{Artikel info}

\section{Artikel history:}

Received;03-11-2020

Revised:20-11-2020

Accepted;07-12-2020

Keyword:

thai tea, coloring agents, sweetening substances.

\section{Kata Kunci:}

thai tea, zat pewarna buatan, zat pemanis buatan
Abstract. Colorants are food additives that can improve or give color to foods. Sweeteners are synthetically processed artificial food additives that do not contain calories and a number of other nutritional values. These dyes and sweeteners can cause allergies such as cough, sensitive throat, and the most severe is impaired blood circulation. The purpose of this study was to determine the use of artificial coloring agents and artificial sweeteners in beverages around the Muhammadiyah Health Polytechnic Makassar. The method used in this research is descriptive and laboratory examination including: qualitative artificial dyes and quantitative artificial sweeteners. The results showed that, from the examination of 3 samples of artificial dyes, the use of Sunset Yellow was found. Meanwhile, from the examination of 2 samples of artificial sweeteners, there was no use of artificial sweeteners. Based on the results of research on Thai Tea drinks, it can be concluded that all samples examined were found to contain dyes made by Sunset Yellow. Meanwhile, from the sample examination, no artificial sweetener was found.

Abstrak. Zat pewarna adalah bahan tambahan makanan yang dapat memperbaiki atau memberikan warna pada makanan. Pemanis adalah bahan tambahan makanan buatan yang diproses secara sintesis yang tidak mengandung kalori dan sejumlah nilai gizi lainnya. Pewarna dan pemanis tersebut bisa menimbulkan alergi seperti batuk, tenggorokan sensitif, dan yang paling parah adalah gangguan sirkulasi darah. Adapun tujuan dari penelitian ini adalah untuk mengetahui penggunaan zat pewarna buatan dan pemanis buatan pada minuman yang di sekitar Politeknik Kesehatan Muhammadiyah Makassar. Metode yang digunakan dalam penelitian ini adalah deksriptif dan pemeriksaan laboratorium meliputi: kualitatif zat warna buatan dan kuantitatif zat pemanis buatan. Hasil penelitian menunjukkan bahwa, dari pemeriksaan 3 sampel zat pewarna buatan ditemukan penggunaan Sunset Yellow. Sedangkan dari pemeriksaan 2 sampel zat pemanis buatan tidak ditemukan penggunaan zat pemanis buatan. Berdasarkan hasil penelitian pada minuman Thai Tea, dapat disimpulkan bahwa semua sampel yang diperiksa ditemukan kandungan zat pewarna 
Studi Kandungan Bahan Tambahan Makanan Pada Minuman Thai Tea Di Sekitar Kampus Politeknik Kesehatan Muhammadiyah Makassar

(A. M. Fadhil Hayat, Baharuddin Sunu, Muhammad Ikbal Abbas, Indah Islamia)

buatan Sunset Yellow. Sedangkan dari pemeriksaan sampel

tidak ditemukan kandungan zat pemanis buatan.

Coresponden author:

Email: fadhil.hayat71@gmail.com

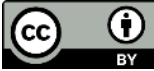

artikel dengan akses terbuka dibawah lisensi CC BY -4.0

\section{PENDAHULUAN}

Makanan sangat penting bagi manusia karena salah satu kebutuhan pokok untuk kelangsungan hidupnya. Untuk itu makanan yang dikonsumsi manusia selain harus terpenuhi kebutuhan gizinya, juga harus terjamin tidak boleh sampai menimbulkan hal-hal yang tidak diinginkan seperti keracunan bahan tambahan makanan yang ditamabahkan makanan.

Masalah keracunan makanan hampir setiap tahun selalu ada dan angka kejadiannya cukup tinggi. Sumber terbesar keracunan makanan yang terjadi di Indonesia berada pada usaha jasa boga atau katering untuk karyawan maupun jajanan anak sekolah.

Dalam mengkonsumsi makanan setiap hari dibutuhkan gizi yang seimbang agar tubuh bisa tetap sehat. Terkadang, meskipun sudah memenuhi syarat makanan empat sehat lima sempurna masih saja gizi yang terkandung dalam makanan empat sehat lima sempurna tersebut masih kurang. Untuk bisa memberikan kebutuhan gizi yang tercukupi dan demi menjaga kontinuitas kesehatan tubuh, masyarakat biasanya mengkonsumsi tambahan suplemen. Suplemen merupakan suatu tambahan multivitamin yang bisa berupa tablet, serbuk sachet, atau dalam bentuk cair (minuman).

Bahan tambahan makanan adalah senyawa atau campuran berbagai senyawa yang sengaja ditambahkan ke dalam makanan dan minuman dalm proses pengolahan, pengemasan dan penyimpanan dan bukan merupakan bahan (ingredient) utama. Pada industri pangan pengolahan pangan umumnya memakai Bahan Tambahan Makanan (BTM) yang meliputi antioksidan, pengatur keasaman, pemanis buatan, pengawet dan pewarna.

Semakin berkembangnya ilmu pengetahuan dan teknologi menyebabkan perubahan yang sangat besar dalam hal pengolahan pangan. Pada saat sekarang ini, banyak bahan-bahan yang ditambahkan ke dalam makanan dan minuman utnuk berbagai disebut Bahan Tambahan Makanan (BTM) (Winarno,1993)

Ada beberapa hal yang dapat menyebabkan suatu bahan pangan berwarna antara lain dengan penambahan zat pewarna. Zat pewarna adalah bahan tambahan makanan yang dapat memperbaiki atau memberikan warna pada makanan. Penambahan pewarna pada makanan dimaksud untuk memperbaiki warna makanan yang berubah atau memucat selama proses pengolahan atau memberi warna pada makanan yang diizinkan dan yang dilarang untuk pangan diatur melalui Peraturan Menteri Kesehatan 
RI Nomor 33 Tahun 2012 mengenai Bahan Tambahan Pangan.

Berdasarkan sumbernya dikenal dua jenis zat pewarna yang termasuk dalam golongan bahan tambahan makanan yaitu pewarna alami dan pewarna buatan. Pewarna alami pada umumnya dianggap aman bagi kesehatan, sedangkan pewarna buatan sering dipermasalahkan karena berbahaya bagi kesehatan.

Demikian juga halnya dengan pemanis buatan. Pemanis adalah bahan tambahan makanan buatan yang diproses secara sintesis yang tidak mengandung kalori dan sejumlah nilai gizi lainnya. Menurut Mudjajanto (2005) penggunaan pemanis buatan yang berlebihan dapat menyebabkan kanker kandung kemih. Dari berbagai penelitian yang dilakukan di Amerika, bahwa efek tidak langsung bahan pemanis buatan ini sebagai penyebab kanker dan relatif lama.

Memasuki era globalisasi saat ini, semua hal telah berkembang secara pesat mengikuti perkembangan zaman. Minuman termasuk salah satunya. Pada saat ini telah viral dikalangan anak muda tentang minuman kekinian seperti “Thai Tea”. Thai tea merupakan minuman khas dari Thailand, minuman varian teh ini sudah mendunia dan bahkan banyak peminatnya di Indonesia. Thai tea merupakan campuran susu kental dan gula dicampur dengan teh sebelum dituangkan di atas es dengan kemudian diatasnya baru diletakkan susu hingga menguap (Galih, 2018).

Namun dari viralnya minuman "Thai tea" tersebut, mungkin ada sebagian oknum yang berbuat curang dengan menambahkan zat pemanis dan pewarna buatan dalam minumannya agar mendapatkan keuntungan lebih besar. Keberadaan zat pemanis dan pewarna buatan yang berlebih pada minuman kemasan yang beredar di masyarakat sangat berbahaya bagi kesehatan. Misalnya dapat memicu kanker dan diabetes.

\section{BAHAN DAN METODE}

\section{A. Lokasi dan Rancangan Penelitian}

Lokasi pengambilan sampel penjual minuman Thai tea di sekitar kampus Politeknik Kesehatan Muhammadiyah Makassar, lokasi pemeriksaan yaitu di Balai Besar Laboratorium Kesehatan Makassar. Metode yang digunakan dalam penelitian ini adalah deksriptif yaitu metode penelitian yang dilakukan dengan tujuan utama untuk membuat gambaran atau mendeskripsikan hasil penelitian berdasarkan data yang diperoleh dari lapangan kemudian menarik suatu kesimpulan. Pemeriksaan laboratorium meliputi: kualitatif zat warna buatan dan kuantitatif zat pemanis buatan.

\section{B. Populasi dan Sampel}

Populasi penelitian adalah semua penjual minuman thai tea yang di sekitar kampus Politeknik Kesehatan Muhammadiyah Makassar sebanyak 3 tempat. Pada penelitian ini sampel yang akan diperiksa zat pemanis buatan dengan menggunakan metode kualitatif sebanyak 3 sampel dan zat pewarna buatan dengan menggunakan metode kuantitatif sebanyak 2 sampel. 
Studi Kandungan Bahan Tambahan Makanan Pada Minuman Thai Tea Di Sekitar Kampus Politeknik Kesehatan Muhammadiyah Makassar

(A. M. Fadhil Hayat, Baharuddin Sunu, Muhammad Ikbal Abbas, Indah Islamia)

\section{HASIL DAN PEMBAHASAN}

\section{A. HASIL PENELITIAN}

1. Zat Pewarna Buatan

Hasil pemeriksaan zat pewarna buatan pada minuman Thai Tea yang dijual di sekitar Politeknik Kesehatan Muhammadiyah Makassar dapat dilihat pada tabel berikut:

Tabel 1. Hasil Pemeriksaan Zat Pewarna Buatan pada Minuman Thai Tea di sekitar Politeknik Kesehatan Muhammadiyah

\begin{tabular}{llll}
\hline No & Sampel & Jenis zat Pewarna & Metode \\
\hline $\mathbf{1}$ & A & Sunset Yellow & $\begin{array}{l}\text { Kromatografi Lapisan Tipis } \\
\text { (KLT) }\end{array}$ \\
\cline { 1 - 2 } $\mathbf{2}$ & B & Sunset Yellow & \\
\hline
\end{tabular}

Sumber: Data Primer, 2019

Pada tabel 1 menunjukkan bahwa ketiga sampel minuman yang diperiksa mengandung zat pewarna Sunset Yellow dan telah sesuai dengan standar Peraturan Menteri Kesehatan Republik Indonesia Nomor 33 Tahun 2012.

\section{Zat Pemanis Buatan}

Hasil pemeriksaan zat pemanis buatan pada minuman Thai Tea yang dijual di sekitar Politeknik Kesehatan Muhammadiyah dapat dilihat pada tabel berikut:

Tabel 2. Hasil Pemeriksaan Zat Pemanis Buatan pada Minuman Thai Tea di sekitar Politenik Kesehatan Muhammadiyah

\begin{tabular}{llll}
\hline No & Sampel & Zat Pemanis & Metode \\
\hline $\mathbf{1 .}$ & D & Negatif & $\begin{array}{l}\text { Kromatografi Lapisan Tipis } \\
\text { (KLT) }\end{array}$ \\
\hline $\mathbf{2}$ & E & Negatif & \\
\hline
\end{tabular}

Sumber: Data Primer, 2019

Berdasarkan tabel 2 diatas diketahui bahwa ke dua sampel thai tea yang diperiksa negatif menggunakan zat pewarna buatan yang diizinkan di Indonesia dan telah sesuai dengan standar Peraturan Menteri Kesehatan Republik Indonesia Nomor 33 Tahun 2012.

\section{B. PEMBAHASAN}

1. Zat pewarna

Pewarna makanan banyak digunakan untuk berbagai jenis makanan atau minuman, terutama berbagai produk serta berbagai makanan atau minuman olahan yang dibuat oleh industri kecil maupun industri rumah tangga meskipun pewarna juga ditemukan pada berbagai jenis makanan atau minuman yang dibuat oleh industri besar.

Selain sebagai faktor yang ikut menentukan mutu, warna juga dapat digunakan sebagai indikator kesegaran atau kematangan. Baik tidaknya cara pencampuran atau cara pengolahan dapat ditandai dengan adanya warna yang seragam dan merata.

Berdasarkan penelitian Galih dan Widiantara (2018), menunjukkan bahwa minuman olahan Thai tea tidak mengandung rhodamin B, tetapi Kelurahan Sarijadi 28,57\% dan Kelurahan Isola 
14,28\% sampel positif mengandung Methanyl yellow. Hal ini sesuai dengan hasil penelitian bahwa semua sampel mengandung pewarna Sunset Yellow dan telah sesuai dengan standar Peraturan Menteri Kesehatan Republik Indonesia Nomor 33 Tahun 2012.

Pemakaian bahan pewarna makanan sinstesis dalam makanan atau minuman walaupun mempunyai dampak positif bagi produsen dan konsumen, diantaranya dapat membuat suatu makanan atau minuman lebih menarik, memperoleh keseragaman warna produk, dan mengembalikan warna dari bahan dasar yang hilang atau berubah selama pengolahan, ternyata dapat pula menimbulkan halhal yang tidak diinginkan dan bahkan mungkin memberi dampak negatif terhadap kesehatan manusia.

Beberapa hal yang mungkin memberi dampak negatif tersebut terjadi bila : bahan pewarna sintesis ini dimakan dalam jumlah kecil, namun berulang; bahan pewarna sintesis dimakan dalam jangka waktu lama; Kelompok masyarakat luas dengan daya tahan yang berbeda-beda, yaitu tergantung pada umur, jenis kelamin, berat badan, mutu makanan atau minuman sehari-hari, dan keadaan fisik; berbagai lapisan masyarakat yang mungkin menggunakan bahan pewarna sintesis secara berlebihan; dan penyimpanan bahan pewarna sintesis oleh pedagang bahan kimia yang tidak memenuhi persyaratan.

Kelebihan pewarna buatan dibanding pewarna alami adalah dapat menghasilkan warna yang lebih kuat dan stabil meski jumlah pewarna yang digunakan hanya sedikit. Warna yang dihasilkan dari pewarna buatan akan tetap cerah meskipun sudah mengalami proses pengolahan dan pemanasan, sedangkan pewarna alami mudah mengalami degradasi atau pemudaran pada saat diolah dan disimpan. Misalnya kerupuk yang menggunakan pewarna alami, maka warna tersebut akan segera pudar ketika mengalami proses penggorengan.

Salah satu jenis pewarna buatan yang digunakan dalam minuman thai tea yang diteliti adalah Sunset Yellow (E110, Orange Yellow/Yellow 6). Sunset Yellow adalah jenis pewarna yang dapat ditemukan dalam makananvseperti jus jeruk, es krim, ikan kalengan, keju, jeli, minuman soda dan banyak obat-obatan.Untuk sekelompok kecil individu, konsumsi pewarna adiktif ini dapat menimbulkan urtikaria, rinitis, alergi, hiperaktivitas, sakit perut, mual dan muntah.

\section{Zat Pemanis buatan}

Pemanis buatan sering ditambahkan ke dalam minuman sebagai pengganti gula karena mempunyai kelebihan dibandingkan dengan pemanis alami (gula). Pemanis berfungsi untuk meningkatkan cita rasa dan aroma, memperbaiki sifat-sifat fisik, sebagai pengawet, memperbaiki sifatsifat kimia sekaligus adalah sumber kalori bagi tubuh, mengembangkan jenis minuman dengan jumlah kalori control, mengontrol program pemeliharaan dan penurunan berat badan, mengurangi kerusakan gigi dan sebagai bahan subtitusi pemanis.

Berdasarkan hasil penelitian Hadju, dkk. (2013) menunjukkan bahwa pada 16 sampel minuman jajanan yang berada di enam pasar tradisional kota Manado, tidak ada yang mengandung pemanis buatan sakarin dan dua sampel es sirup mengandung pemanis buatan siklamat. Hal ini sesuai 
Studi Kandungan Bahan Tambahan Makanan Pada Minuman Thai Tea Di Sekitar Kampus Politeknik Kesehatan Muhammadiyah Makassar

(A. M. Fadhil Hayat, Baharuddin Sunu, Muhammad Ikbal Abbas, Indah Islamia)

dengan hasil penelitian bahwa semua sampel menunjukkan negatif zat pemanis buatan dan telah sesuai dengan standar Peraturan Menteri Kesehatan Republik Indonesia Nomor 33 Tahun 2012.

Pemanis ditambahkan ke dalam makanan atau minuman mempunyai beberapa tujuan diantaranya sebagai berikut :

a) Sebagai makanan atau minuman bagi penderita diabetes mellitus karena tidak menimbulkan kelebihan gula darah. Pada penderita diabetes mellitus disarankan menggunakan pemanis buatan untuk menghindari bahaya gula.

b) Memenuhi kebutuhan kalori rendah untuk penderita kegemukan yang merupakan salah satu faktor penyakit jantung yang merupakan penyebab utama kematian. Untuk orang yang kurang aktif secara fisik disarankan untuk mengurangi masukan kalori per harinya. Pemanis buatan merupakan salah satu bahan makanan atau minuman untuk mengurangi masukan kalori.

c) Menghindari kerusakan gigi seperti pada permen lebih sering ditambahkan pemanis sintesis karena bahan permen ini mempunyai rasa manis yang lebih tinggi dari gula, pemakaian dalam jumlah sedikit saja sudah menimbulkan rasa manis yang diperlukan sehingga tidak merusak gigi.

d) Pada industri makanan atau minuman, termasuk industri rokok, pemanis buatan dipergunakan dengan tujuan untuk menekan biaya produksi, karena pemanis sintesis ini selain mempunyai tingkat rasa manis yang lebih tinggi juga harganya relatif murah dibandingkan dengan gula yang diproduksi di alam.

\section{KESIMPULAN}

Berdasarkan hasil penelitian pada minuman Thai Tea, dapat disimpulkan bahwa semua sampel yang diperiksa ditemukan kandungan zat pewarna buatan Sunset Yellow. Sedangkan semua sampel yang diperiksa tidak ditemukan kandungan zat pemanis buatan.

\section{DAFTAR PUSTAKA}

Anwar, S. (1990). Pedoman Bidang Studi Sanitasi Makanan dan Minuman pada Institusi Pendidikan Tenaga Sanitasi.

Galih, N. R., \& Widiantara, T. (2018). Identifikasi Kandungan Sakarin, Siklamat, Rodhamine B dan Methanyl Yellow Pada Produk Minuman Olahan Thai Tea Di Kecamatan Sukasari Bulan Agustus-Tahun 2018 (Doctoral dissertation, Fakultas Teknik Unpas).

Hadju, N. A., Tuju, T. D., Ludong, M. M., \& Langi, T. M. (2013, January). Analisis zat pemanis buatan pada minuman jajanan yang dijual di pasar tradisional kota Manado. In COCOS (Vol. 2, No. 1).

Irawan, W. K. (2018). Pengaruh kualitas produk terhadap minat pembelian ulang pada Dumdum Thai Tea di Kota Bandung. 
Manurung, E. (2010). Analisa Kadar Tartrazine dan Sunset Yellow dalam Serbuk Minuman Nutrisari dengan Metode Spektrofotometri.

Mudjajanto, E. S. (2005). Keamanan Makanan Jajanan Tradisional dalam Makan Sehat Hidup Sehat. Kompas. Jakarta.

Mulia, R. M. (2005). Kesehatan lingkungan. Yogyakarta: Graha Ilmu.

Napitupulu, L. H. (2006). Analisa Zat Warna Dan Pemanis Buatan Pada Es Krim Yang Dijajakan Di Beberapa Pasar Kota Medan Tahun 2005.

Noor, M. F. (2014). Pengaruh Brand Image dan Brand Trust Terhadap Brand Loyalty King Thai Tea Bandung. Image: Jurnal Riset Manajemen, 3(2), 109.

Permenkes, R. I. No. 33 Tahun 2012 Tentang Bahan Tambahan Pangan.

Ratnani, R. D. (2009). Bahaya bahan tambahan makanan bagi kesehatan. MAJALAH ILMIAH MOMENTUM, 5(1).

Saparinto, C., \& Hidayati, D. (2006). Bahan tambahan pangan. Kanisius.

Winarno, F. G. (1993). Pangan: Gizi, Teknologi dan Konsumen. Gramedia Pustaka Utama. 